\title{
Human Resource Management of Contract-Based Teachers and Education Staff to Ensure Quality Education of Senior High Schools in North Sumatera Province
}

\author{
Zahraini \\ Universitas Negeri Medan \\ Medan, Indonesia \\ zahraini_za@yahoo.co.id
}

\author{
Benyamin Situmorang \\ Universitas Negeri Medan \\ Medan, Indonesia \\ benyaminsitumorang@gmail.com
}

\begin{abstract}
The purpose of this study was to describe the human resource management system used in the senior high schools to improve the quality of teaching and learning process. It was a qualitative approach with the data obtained from observation, interviews, field studies, and documents. The subjects were principals and the teachers. The results indicate that the recruitment system had not utilized the competency test because there were several civil servant teachers, contract-based teachers and education staff who were not able to develop lesson plans, syllabus, and learning media appropriate to the topics of learning. The career development of the teachers and education staff was still based on the instructions of the principals. The placement of the teachers and staff was still not in accordance with the principle of the right man on the right place, so there was a mismatch between the educational background of the teachers and the subjects taught by them. Most contract-based teachers and education staff have not carried out their duties properly due to a lack of government attention to the general welfare of them. It was concluded that to ensure quality education, the development of the teachers and education staff must be considered seriously. The government has already implemented a program of Contract-Based Government Employee or P3K since 2019 as one of the best solutions for this problem. This program has just been implemented for contractbased employees with Category 2 or K2 status, which currently ranges from 159,000 people.
\end{abstract}

\section{Keywords-Management; Teachers and Education Staff}

\section{INTRODUCTION}

Improving the quality of learning is motivated by advances in science and technology, especially information technology. This is a challenge for life in the future. However, on the other hand, it becomes hope and a threat to the Indonesian people who are not ready to face it. In order to survive in this era, a prerequisite is needed, that is, the ability to compete globally in improving the quality of human resources. In the formation of quality resources, the existence of education is a major factor that must get serious attention from all parties.
Educators and education personnel are one of the National Education Standards which require special attention from the government and the community. An important view of educators is as follows. (1) Teachers expected now; (2) The task of the teacher as a vocation; (3) Democratic teachers; (4) Professional teachers; (5) Improving teacher quality. Regarding educational staff, enlightenment is needed, enlightenment can be carried out through a human resource approach, which includes: (1) competence, (2) certification, (3) qualifications, (4) recruitment and selection, (5) career development, (6) performance assessment, (7) rewards and protections, and (8) dismissals. Quality learning changes in the approach to human resources as mentioned above.

To improve the welfare of teachers or educators and education personnel, the Governor of North Sumatra in 2019 has raised the salary of non-permanent teachers by 50 thousand rupiahs per hour [1]. This is in accordance with the 2018-2023 Regional Medium-Term Development Plan (RPJMD) set in the North Sumatra House of Representative plenary meeting.

Phenomenology of research results to find out (1) planning of contract-based teacher and education staff at SMA Negeri 1 Perbaungan, SMA Negeri 2 Lubuk Pakam and SMA Negeri 3 Medan and SMA CT Foundation (2) recruitment of contractbased teacher and education staff (3) placement of educators and educationstaff (4) teacher and education staff development activities.

The quality of human resources in several high schools in North Sumatra Province is still below the Indonesian Education Standards, one of the high schools in North Sumatra Province, that is SMA Negeri 2 Lubuk Pakam is still far from expectations. The ability of both teachers and education staffmust be further improved. There are still teachers who are a mismatch in the field of subjects being taught and the majority of teachers and education staff do not master IT [2]

The need to describe the related human resource management system regarding planning, recruitment, 
placement, and development of educators and education personnel in schools in North Sumatra Province to improve the quality of learning.

\section{RESEARCH}

\section{A. Research Approach}

In this study, qualitative methods were collected from interview scripts, field notes, personal documents, and other official documents. So that the purpose of qualitative research is to describe the reality behind the phenomenon in-depth, in detail and thoroughly. Therefore the use of a qualitative approach in this study is to match reality with the prevailing theory using descriptive methods. Qualitative research is often called the naturalistic research method because the research is carried out in natural conditions (natural setting); also called the ethnographic method, because initially this method was more widely used for research in the field of cultural anthropology; also called a qualitative method, because the data collection and analysis are more qualitative. According to Sugiyono qualitative research can be interpreted as a research method based on the philosophy of post positivism, used to examine natural conditions of objects, (as opposed to being experiments) in which researchers as key instruments, data collection techniques are carried out by triangulation (combined), data analysis is inductive/ qualitative, and qualitative research results emphasize more meaning than generalization [3].

\section{B. Research Location and Time}

The location and time of the study are very important parts planned properly. This research was conducted in four schools in North Sumatra, namely SMAN I Perbaungan, SMAN 2 Lubuk Pakam, SMAN 3 Medan, and SMA Unggul CT Foundation. Field research has been carried out from September 2017 to March 2019.

\section{Research Subject}

Subjects are all research objects that are sources of data in the form of humans, symptoms, objects, and events. In accordance with the focus of research on the management of educators and education staff to improve the quality of learning, the subjects in this study are: (1) Principals of State High Schools in North Sumatra (2) State High School Teachers in North Sumatra (3) Education staff in North Sumatra State High School (4) Head of Curriculum Division of North Sumatra Province Education Office. According to Sugiyono the population is a region of generalization consisting of subjects having certain quantities and characteristics determined by researchers to be studied and then drawn conclusions [3].

\section{Data Collection Technique}

Data collection can be done in a variety of settings, sources, and ways. When viewed from its settings, data can be collected in natural settings, in laboratories with experimental methods, in schools with education and education personnel, at home with various respondents, at a seminar, discussion, and others. When viewed from the data source, the data collection can use primary sources and secondary sources. Primary sources are data sources that directly provide data to data collectors, and secondary sources are sources that do not directly provide data to data collectors, for example through other people or through documents.

\section{E. Data Analysis Technique}

The data processing stage is a very important part of the research. After the raw data is collected, the data is then analyzed. According to Sugiyono data analysis is the process of systematically searching for and compiling data obtained from interviews, field notes, and documentation by organizing data into categories, breaking down into units, synthesizing, compiling into pattern, choose what is important and what will be learned, and make conclusions so that it is easily understood by yourself and others [3]. Before conducting the analysis activity, the data is processed in order to make it easier for researchers to organize research results accurately.

The data analysis process in this study was carried out continuously from beginning to end, both in the field and outside the field. Data analysis in the field includes recording, coding and temporary interpretation of various information obtained at various steps of the study.

To obtain the validity and accuracy of data obtained from the field, a check is made of the data obtained using other trusted resources, making it possible to produce an accurate and credible research data.

\section{F. Research Instrument}

The research instrument is an aid in data collection. The quality of the instrument can determine the quality of the data collected. According to Sugiyono the research instrument is a tool used to measure observed natural and social phenomena". The instrument in this study is the researcher himself because in research that uses a qualitative approach the researcher is a key instrument [3]. Moleong states that the characteristics of qualitative research cannot be separated from participant observation, but the role of the researcher determines the overall scenario [4].

To obtain data on the management of educators and education personnel to improve the quality of education in SMA 1 Perbaungan, SMA N.2 Lubuk Pakam, SMA N.3 Medan and SMA Unggul CT Foundation, the researcher will be an instrument because in qualitative research the researcher is a key instrument.

\section{G. Credibility Test}

The credibility test is used to see the extent of the compatibility of the construction between the data that has been obtained in the field with the problem being examined. According to Sugiyono testing the validity and reliability of data in qualitative research includes testing the credibility of qualitative research data, including Extension of observation, increased persistence in research, triangulation, analysis of 
negative cases, using reference materials, checking [3]. The process of checking data obtained by researchers to the data giver. The purpose of checking to find out the extent to which the data obtained is in accordance with what is provided by the data provider. Implementation of member checking can be done after a period of data collection is completed, or after getting a finding or conclusion.

The credibility test in this study is expected so that researchers can analyze the suitability of the data obtained both the symptoms, activities, and events related to the leadership behavior of the principal in improving the quality of school personnel, in the context of space, time and situations experienced to improve the quality of learning.

\section{RESULT AND DISCUSSION}

\subsection{Contract-Based Teachers and Education Staff Planning}

The results of the interviews and observations about the accreditation of school principals from SMA Negeri 1 Perbaungan provide information:

Accreditation of Perbaungan 1 High School is B, this school was built in 1980 and there are some teachers with different educational backgrounds from the fields taught so that the accreditation assessment gets $a B$.

The principal said:

The number of educators and education personnel in SMA 1 Perbaungan is not enough when compared to the number of students, I expect the Education Office to accept the contractor non-permanent teachers for our school.

Furthermore, the school principal added: Muchnonpermanent staff at the school were not yet professional due to the government's lack of attention towards the professional development of non-permanent teachers.

The process of the needs of teachers and education personnel planningensures that schools have an appropriate number and type of staff to be able to carry out work programs correctly and appropriately towards achieving goals effectively and efficiently.

From the results of the interview with the principal of the SMA Lubuk Pakam, he explained the planning of the nonpermanent teachers and Education staff as follow:

I always predict the needs of teachers and education staff every year, project, compare the needs of educators and education personnel predicted with those projected, determine how to meet the needs of educators and education staff.

The principal of SMA CT Foundation explains why the need for education personnel planning:

I set the formation at the High School CT Foundation to balance the needs, so I planned the need to balance the proportion of the number of teachers and education personnel, know the trends of educators and non-permanent staff who will enter retirement age, make plans to project the needs of educators and education personnel for 5 years and 10 years.

Based on the results of the interview above it can be concluded that planning is the first step in every move of an organization, in other words, Human resource planning is the first function of HRM.

The government has planned the Government Employee Program with a Work Agreement (PPPK) or P3K 2019. The implementation of P3K 2019 as one of the best solutions for employment problems in the regions. This program has only been implemented for non-permanent teachers with category 2 (K2) status, currently around 159 thousand people.

\subsection{The Recruitment of Contract-Based Teacher and Education Staff}

Based on interviews with school principals and viceprincipals, the recruitment of education staff is based on specific expertise with duties and responsibilities based on competence. The SMA CT Foundation principal explains:

$I$ provide a policy that recruitment of education personnel must be adjusted to the needs of schools and areas of expertise. Recruitment at the CT Foundation is a contract with the Foundation,

Furthermore, the vice Principal of the SMA 2 Lubuk Pakam said:

The recruitment of non-permanent staff is more related to the position of School Principal and School Superintendent which is determined by the Regent based on political approach, either through the emotional relations of political parties or involvement as a member of the successful team to win the election or referred to as political reciprocity.

Research data related to the recruitment of teachers and non-permanent teaching staff indicate that the CT Foundation determines qualifications. Teacher qualifications include minimum teacher qualifications level $\mathrm{S} 1$, teachers meet the level of authority and suitability based on teacher certificates, teachers are expected to have competency certificates, teachers are able to use ICT in teaching and learning based on internet and Blogger models, suitability of educational background must be in accordance with subjects who are supported, have the knowledge and experience needed and prioritize S1 or S2 University graduates with A Accreditation.

\subsection{The Placement of Contract-Based Teacher and Education Staff}

Based on the interview with the principal of SMA CT Foundation, he explained that: Our placement of educators refers to the principle of the right man in the right place.

However, it differs from SMA 1 Perbaungan, the principal gave a statement:

The non-permanent teachers still have a $30 \%$ mismatch between the educational background and the subjects being taught;

While in SMA N.2 Lubuk Pakam, there are still teachers who teach not in accordance with educational qualifications.

Placement of teachers and education personnel must be appropriate so that educators and education personnel can carry out their duties in an effective, effective and efficient manner, which requires several things, namely diploma background, work experience, possibilities for career development and improvement, attitudes or appearance. 


\subsection{Development Activities for Contract-Based Teacher and Education Staff}

Based on interviews and field observations, the principal of SMA Negeri 1 Perbaungan explained:

At SMA Negeri 1 Perbaungan, there is an opportunity for honorary teachers to develop themselves to become superior, moral, and hard-working teachers with a directional conscience like this given at school.

Furthermore, development takes place in the community and work environments. Vice-principal for Curriculum Affairs of SMA Negeri 1 Perbaungan said that in addition to lack of mastery in their fields, there were still many contract-based teachers who lacked learning models so that in teaching they only used those models.

Teachers teach more in a way that they like themselves and pay less attention to what their students like. Furthermore, based on interviews with the principal of SMAN 3 Medan, he stated that:

"I am very concerned about the development of human resources non-permanent teachers and education staff to be "superior, moral, and hard-working because it is in accordance with the vision and mission of SMA N 3 Medan."

This high school highly prioritizes the quality of teachers to make quality education in SMA Negeri 3 Medan. There is little difference with the CT Foundation High School which provides the basis for the development of teacher work skills, SMA 3 Medan provides the basis for the development of academic skills and life skills that are general to teachers and will be explained to students. The CT Foundation high school principal explains:

"CT Foundation schools have always budgeted funds for activities to develop educators and education personnel, and I set this every year if there are teachers whose performance is not good we will prioritize."

Teacher quality improvement according to the UNESCO model is as follows: teacher pre-service education, teacher certification or diploma, recruitment and placement of teachers, working conditions of teachers, and high teacher salaries will attract young people.

Non-permanent and permanent teachers play a key role in education, but attention to them is still far from satisfying. The level of welfare of honorary staff is low and does not match the workload, while their career development systems are not clear. Even sadder, they often get unfair treatment from bureaucracy like ordinary office employees, for example, they have to attend meetings, line up, wear the same uniform as office employees, take care of promotions to which they are entitled and by giving awards.

Some award models such as special achievement guarantees for teaching staff and honorary educators are very good and produce a lot of educational innovations.

Based on interviews with the principal of SMA Lubuk Pakam about professional teachers that: there are still some non-permanent teachers who are less competent in their fields.

A contract-based teacher from SMA N 1 Perbaungan gave a reason that suggests that:
"I am not competent, for example when studying or studying has not really mastered the material."

From the above interview, it can be concluded that there are teachers who are not the best graduates. They are not the best students entering prospective teachers. The quality of lecturers who guide and accompany student teacher candidates is also influential and there are teachers teaching who are not in their fields.

\section{CONCLUSION}

The contract-bases teachers and education staff in North Sumatra Province are required to be able to carry out their main duties properly in carrying out their tasks. Carrying out basic tasks in accordance with educational background has the opportunity to develop abilities better than those not in accordance with their educational background. To face the challenges of global competition, teachers are expected to have a whole personality, virtuous, honest, mature, faithful, moral, disciplined, responsible, broad-minded, etc. Now, in addition to the need for the non-permanent teachers who have good personalities, teachers who are creative and open to all the changes are also needed and advancements available for student progress.

Two main things in the development of education staff are (1) The recruitment pattern of education staff, (2) Development of education staff competencies. Field observations show that there are three patterns of approach that become policy choices in the recruitment of education personnel, namely (1) approaches based on professionalism principles, (2) political approaches of reciprocity and good relations, (3) geographical regional approach due to regional autonomy.

Better salaries will lead to better quality learning. With the increase of the salary of non-permanent teachers and education staff, so that they will not look for another project outside school.

Some award models such as special achievement guarantees for the non-permanent education staff and teachers are very good and produce a lot of educational innovations.

\section{ACKNOWLEDGMENT}

Thanks to all parties who have provided moral and material assistance, especially to: the international advisory board committe by Dr. Rahmad Husein, M. Ed.- Confrence Chair, DR. Juniastel Rajagukguk, M.Sc., Dr. Rahmat Mulyana, M. Si. and Dr. E. Elvis Napitupulu, M.S. Thank you deeply to Indexed by Thomson Reuters, Compendex, NKI Scholar, and Geoogle Scholar and author's respect for the entire academic community of the Medan State University Graduate Program and Murdoch University Perth, Western Australia. Thank you also to the author, to LPDP, Ministry of Finance of the Republic of Indonesia for funding the author's education fund for the International Seminar. Finally, for the service kindness of the parties who have helped the 
completion of this article and the implementation of International seminar may receive multiple replies from God Almighty and hopefully this article will be useful for readers in general and especially readers in the field of management education.

\section{REFERENCES}

[1] JawaPos.com, Februari 2019.

[2] Maimun and Fitri, "Pengembangan Profesionalitas Pendidik dan Tenaga Pendidikan Terhadap IT". Medan. 2010, p. 7.

[3] Sugiyono, Manajemen Strategik dalam Peningkatan Mutu Pendidikan, Bandung: Alfabeta, 2013

[4] J.L. Moleong, Metodologi Penelitian Kualitatif, Bandung: PT. Remaja Rosdakarya, 2006 